\title{
Pengaruh Kompensasi Non Finansial terhadap Kinerja Guru SDN Tinap 2 Kecamatan Sukomoro Kabupaten Magetan
}

\author{
Intania Rahma Dewanti $\bowtie$, Universitas PGRI Madiun \\ Muhammad Hanif,Universitas PGRI Madiun
}

\intaniarahma@gmail.com

\begin{abstract}
Abstrak. Penelitian ini bertujuan untuk mendeskripsikan dan menjelaskan latar belakang pemberian kompensasi non finansial, jenis kompensasi non finansial serta pengaruhnya terhadap kinerja Kompensasi non finansial terhadap kinerja guru di SDN Tinap 2 Kecamatan Sukomoro Kabupaten Magetan. Penelitian ini menggunakan pendekatan kualitatif deskriptif. Penelitian dilaksanakan di SDN Tinap 2 mulai bulan JanuariAgustus 2019. Sumber data yang digunakan pada penelitian yakni data primer dan sekunder, sedangkan teknik pengumpulan datanya adalah dengan wawancara, observasi dan dokumentasi. Data yang diperoleh dianalisis dengak teknik kualitatif model interaktif. Dari penelitian diperoleh hasil bhwa latar belakang diadakannya kompensasi non finansial karena adanya keinginan guru untuk mendapatkan sebuah motivasi atau dorongan untuk mendukung guru lebih giat dan semangat dalam bertugas. Sedangkan kompensasi non finansial memberikan pengaruh yang positif terhadap kinerja guru SDN Tinap 2. Kompensasi non finansial yang diberikan di SDN Tinap 2 berupa (1) pendidikan dan pelatihan (diklat), (2) Promosi, (3) lingkungan yang bersih dan nyaman, (4) Nyaman dalam bertugas, (5) Pujian. Kompensasi non finansial juga memberikan pengaruh terhadap kinerja guru di SDN Tinap 2 Kecamatan Sukomoro Kabupaten Magetan.
\end{abstract}

Kata Kunci : Kinerja Guru; Kompensasi Non finansial

Abstract. This study aims to describe and explain the background of the provision of non-financial compensation, types of non-financial compensation and its effect on the performance of non-financial compensation on teacher performance at SDN Tinap 2 Sukomoro District, Magetan Regency. This study uses a descriptive qualitative approach. The research was carried out at SDN Tinap 2 starting from January-August 2019. The data sources used in the study were primary and secondary data, while the data collection techniques were interviews, observation and documentation. The data obtained were analyzed using a qualitative interactive model technique. From the research, it was found that the background of holding non-financial compensation was because of the teacher's desire to get a motivation or encouragement to support teachers to be more active and enthusiastic in their duties. While non-financial compensation has a positive influence on the performance of SDN Tinap 2 teachers. Non-financial compensation provided at SDN Tinap 2 is in the form of (1) education and training (training), (2) promotion, (3) a clean and comfortable environment, 4) Comfortable in duty, (5) Praise. Non-financial compensation also has an influence on teacher performance at SDN Tinap 2, Sukomoro District, Magetan Regency.

Keywords: Teacher Performance; Non-financial Compensation

Citation: Dewanti, R.I., \& Hanif, M. (2022). Pengaruh Kompensasi Non Finansial terhadap Kinerja Guru SDN Tinap 2 Kecamatan Sukomoro Kabupaten Magetan. Wewarah: Jurnal Pendidikan Multidisipliner, 1(1), 55 - 60. 


\section{PENDAHULUAN}

Secara sederhana guru bisa dikaitkan dengan pengajar atau sebagai tenaga pendidik yang merupakan salah satu faktor penentu keberhasilan setiap usaha dan upaya dalam sistem pendidikan. Seorang guru yang profesional pada hakikatnya memiliki niat, pemahaman, kesadaran, komitmen serta keperdulian yang tinggi untuk mengabdikan dirinya kepada masyarakat oleh karena itu guru sebagai pekerja profesional dituntut untuk memiliki kepribadian serta kemampuan yang baik dan stabil agar dapat memberikan suatu layanan profesional yang bermutu. Dengan profesi guru hendaknya setiap guru harus sadar dan paham untuk memiliki komitmen yang tinggi untuk mengabdikan dirinya kepada masyarakat melalui dunia pendidikan.

Guru bisa dikatakan suatu sumber daya manusia yang memberikan ilmu pendidikan kepada peserta didik, juga sangat berpengaruh terhadap mutu pendidikan sehingga guru dituntut untuk dapat memiliki suatu kinerja yang tinggi untuk meningkatkan sumber daya manusia yang memadai. Guru juga sangat berpengaruh terhadap terciptanya suatu proses dari hasil pendidikan yang berkualitas sehingga akan terbentuk peserta didik yang berkualitas serta guru juga dituntut untuk memiliki berbagai kompetensi dasar, yaitu kompetensi pedagogik, kompetensi kepribadian, kompetensi sosial, dan yang terakhir kompetensi profesional. Danim (2011) mengatakan bahwa guru merupakan pendidik profesional dengan tugas utama mendidik, mengajar, membimbing, mengarahkan, melatih, menilai, dan mengevaluasi siswa pada jalur pendidikan formal. Kinerja guru bertambah baik atau buruk biasanya dipengaruhi oleh berbagai macam faktor salah satunya dengan pemberian imbal jasa yang diterima atau sering disebut kompensasi, karena dengan adanya kompensasi maka guru mendapatkan sumber penghasilan bagi mereka dan keluarganya.

Kinerja guru dapat diartikan sebagai tingkat keberhasilan guru dalam melaksanakan tugas pendidikan sesuai dengan tanggung jawab dan wewenangnya berdasarkan standar kinerja yang telah ditetapkan selama periode tertentu dalam kerangka mencapai tujuan pendidikan, kinerja guru dapat dapat dilihat dari dan diukur berdasarkan speksifikasi kompetensi yang harus dimiliki oleh setiap guru (Arifin dan Barnawi, 2014). Baik atau buruknya suatu kinerja guru dipengaruhi oleh berbagai faktor, satu diantaranya adalah pemberian kompensasi yang diterima guru. Supardi juga mengutarakan bahwa kinerja guru merupakan kemampuan seorang guru dalam melaksanakan tugas pembelajaran di sekolah dan bertanggung jawab atas peserta didik di bawah bimbingannya dengan meningkatkan prestasi belajar peserta didik (Kompri, 2016). Dengan demikian dapat disimpulkan dari beberapa pengertian kinerja guru di atas bahwa kinerja guru dapat diartikan sebagai keberhasilan pendidik atau guru dalam melaksanakan tugas sesuai dengan kinerja yang telah ditetapkan dalam rangka mencapai tujuan pendidikan. Kinerja guru juga dapat diartikan yaitu merupakan suatu kemampuan yang ditujukkan guru dalam melaksanakan suatu tugas atau pekerjaannya sehingga apabila kinerja dianggap baik dan memuaskan maka tujuan dan harapan dapat dicapai sesuai dengan standar yang telah ditetapkan.

Tujuan pemberian kompensasi secara umum tujuan pemberian kompensasi berarti dapat memberi pengaruh positif dan signifikan terhadap kinerja guru, sehingga pemberian kompensasi yang tinggi pada guru juga dapat memacu kesungguhan guru dalam bekerja (Suhardiman, 2012). Tujuan pemberian kompensasi kepada pegawai pada hakikatnya tidak hanya untuk memenuhi kebutuha pegawai yang bersangkutan, tetapi lebih jauh dari itu, yaitu untuk mempercepat pencapain tujuan organisasi/perusahaan. Pemberian kompensasi dilaksanakan dengan harapan bisa memberikan kepuasan kepada semua pihak, baik karyawan maupun perusahaan sehingga karyawan dapat memenuhi kebutuhan hidupnya dengan adanya kompensasi, dan perusahaanpun mendapatkan laba atau keuntungan. Martoyo (dalam Samputri, 2012) menyampaikan lebih rinci yaitu: (1) Pemenuhan kebutuhan ekonomi karyawan atau sebagai jaminan economic security bagi pahlawan, (2) Mendorong agar karyawan lebih baik dan lebih giat, (3) Menunjukkan bahwa perusahaan mengalami kemajuan, (4) Menunjukkan pengahrgaan dan perlakuan adil organisasi terhadap karyawannya. Hal serupa disampaikan Sadili Samsudin (dalam Yusuf, 2016) bahwa pemberian kompensasi di dalam suatu organisasi dapat berfungsi, (1) Pengalokasian sumber daya manusia secara efisien, (2) Mengumumkan sumber daya manusia secara lebih efisien dan efektif, dan (3) Mendorong stabilitas dan pertumbuhan ekonomi. Jadi tujuan pemberian kompensasi pada intinya untuk memotivasi seseorang dalam bekerja agar dapat bekerja lebih baik sehingga pencapain tujuan akan cepat tercapai serta guru juga berhak untuk mendapatkan kompensasis sesuai dengan peraturannya. Dengan pemberian kompensasi yang adil akan membuat karyawan akan lebih disiplin dalam setiap pekerjaan yang dijalankannya serta juga dapat menciptakan suatu efektifitas kerja yang bagus.

Dalam penelitian yang dilakukan oleh Shaftani (2010) menunjukkan bahwa pemberian kompensasi berpengaruh positif dan signifikan terhadap kinerja guru, sehingga pemberian kompensasi yang tinggi pada guru dapat memacu kesungguhan dan memotivasi guru dalam bekerja. Menurut Suhardiman (2012) kompensasi ini pada hakikatnya merupakan penghargaan atau imbalan kepada pegawai atas jasa/pekerjaannya untuk kepentingan organisasi. Pemberian kompensasi merupakan hal yang perlu diperhatikan dalam fungsi operasional manusia, karena tujuan manusia dalam bekerja adalah untuk mendapatkan imbalan atau jasa guna memenuhi kebutuhan mereka. Kompensasi yang diterima guru bisa berupa kompensasi finansial dan kompensasi non finansial. Kompensasi finansial merupakan kompensasi yang diterima oleh guru dalam bentuk uang yang meliputi gaji, insentif, serta tunjangan. Untuk kompensasi non finansial merupakan kompensasi dalam bentuk non uang yang meliputi kesempatan bagi guru untuk mendapatkan promosi peningkatan karier, pengembangan 
diri, serta suasana lingkungan kerja. Kompensasi non finansial (nonfinansial compensation) terdiri atas kepuasan kerja yang diperoleh seseorang dari pekerjaan itu sendiri atau dari lingkungan psikologis di mana orang itu bekerja tipe kompensasi non finansial meliputi kepuasan yang didapat dari pelaksanaan tugas yang signifikan yang berhubungan dengan pekerjaan (Tiyadi, 2011).

Berdasarkan uraian di atas pemberian kompensasi non finansial terhadap variabel kinerja guru di SDN Tinap 2 Kecamatan Sukomoro Kabupaten Magetan menarik diteliti. Adapun tujuannya yaitu untuk mendeskripsikan dan menjelaskan pengaruh pemberian kompensasi non finansial terhadap kinerja guru SDN Tinap 2.

\section{METODE PENELITIAN}

Penelitian ini akan menggunakan pendekatan kualitatif dengan jenis penelitian deskriptif. Sedangkan tempat penelitiannya di SDN Tinap 2 Kecamatan Sukomoro Kabupaten Magetan. Penelitian penelitian ini dilakukan selama mulai bulan Januari 2018 sampai dengan bulan Agustus 2019.

Sumber data penelitian ini menggunakan sumber data primer dan sumber data sekunder yang dapat menjelaskan informasi yang diperlukan dalam penelitian. Data diambil dengan menggunakan metode wawancara. Dalam penelitian ini, data yang diperoleh melalui wawancara merupakan data primer. Arikunto (2013: 198) wawancara merupakan dialog antara pewawancara dengan terwawancara yang dilakukan untuk memperoleh informasi Teknik wawancara menjadi bagian dari penelitian kualitatif, setelah menggunakan teknik observasi selanjutnya peneliti akan menggunakan teknik wawancara sebagai penyempurna pengambilan data. Metode ini dipakai dalam penelitian karena peneliti akan melakukan wawancara kepada informan yang dianggap sebagai sumber yang mampu menjawab dari rumusan masalah penelitian. Penelitian ini akan menggunakan wawancara terstruktur, wawancara terstruktur digunakan sebagai teknik pengumpulan data, dalam wawancara terstuktur ini peneliti telah menyiapkan instrumen penelitian berupa pertanyaan-pertanyaan tertulis yang alternatiif jawabannya telah disiapkan. Kemuidan yang kedua menggunakan teknik observasi, penelitian ini akan dilakukan dengan observasi secara langsung. Menurut Nasution (dalam Sugiyono, 2016) menyatakan bahwa "observasi adalah dasar semua ilmu pengetahuan". Kemudian teknik terakhir yang digunakan adalah dengan dokumentasi. Dokumen merupakan catatan peristiwa yang sudah berlalu. Dokumen bisa berbentuk tulisan, gambar, atau karya-karya monumental dari seseorang”. Dokumen berbentuk gambar misalnya foto, gambar hidup, dan lain-lain. Dokumentasi adalah suatu metode pengumpulan data kualitatif dengan melihat serta menganalisis dokumen yang telah dibuat. Menggunakan metode dokumentasi ini dengan tujuan untuk memudahkan dalam mendapatkan data yang diperlukan peneliti kemudian juga membuat kemudahan apabila terjadi suatu data yang hilang.

Data yang diperoleh dianalisis dengan teknik kualitatif model interaktif melalui tiga tahap yaitu: (1) Tahap Reduksi Data, dalam tahap reduksi data, peneliti melakukan proses memilih hal-hal yang pokok, penyederharnaan serta melakukan asbtraksi data dari sumber penelitian, dengan cara ini peneliti lebih mudah untuk mendapat gambaran data yang telah direduksi untuk melakukan pengumpulan data. (2) Tahap Penyajian Data, sajian data merupakan suatu rakitan organisasi deskripsi, informasi, yang berupa dalam bentuk narasi yang dimana sajian ini merupakan suatu rangkaian kalimat yang disusun secara sistematis dan logis dengan tujuan agar peneliti lebih mudah untuk memahami objek yang akan diteliti dan dapat memberikan suatu jawaban sesuai dengan rumusan masalah. (3) Tahapan Penarikan Kesimpulan, penarikan kesimpulan dalam penelitian kualitatif ini mungkin dapat menjawab ruusan masalah tetapi mungkin juga tidak, karena masalah dan rumusan masalah dalam penelitian kualitatif masih bersifat sementara. Kesimpulan dalam penelitian kualitatif adalah merupakan temuan baru yang sebelumnya belum pernah ada. Kesimpulan awal yang dikemukakan masih bersifat sementara, dan akan berubah apabila tidak ditemukan bukti-bukti yang kuat untuk mendukung tahap pengumpulan data berikutnya,namun apabila kesimpulan yang dituliskan pada tahap awal didukung oleh bukti yang valid dan konsisten, maka kesimpulan yang dikemukakan merupakan kesimpulan yang kredibel.

\section{HASIL PENELITIAN DAN PEMBAHASAN Hasil Penelitian}

Dalam penelitian ini terdiri dari dua variabel, yaitu variabel pemberian kompensasi non finansial dan kinerja guru. Pemberian kompensasi non finansial dan kinerja guru di SDN Tinap 2 bertujuan berpengaruh positif terhadap kinerja guru, sehingga pemberian kompensasi yang tinggi pada guru juga dapat memacu kesungguhan guru dalam bekerja. Berdasarkan hasil penelitian yang dilakukan menunjukkan peneliti bahwa adanya latar belakang diadakannya kompensasi non finansial karena adanya suatu keinginan guru untuk mendapatkan suatu kepuasan diri dan kenyamanan dalam bekerja serta kenyamanan dalam bertugas sehingga kinerja guru diharapkan akan semakin meningkat kemudian juga adanya keinginan untuk cepat naik pangkat atau golongan dalam waktu yang tepat atau tidak tertunda.

Kompensasi non finansial yang diberikan kepada guru SDN Tinap 2 bertujuan untuk mendorong kinerja guru agar lebih baik lagi, jenis kompensasi yang diterima di SDN Tinap 2 adalah (1) pendidikan dan pelatihan (diklat), (2) Promosi, (3) lingkungan yang bersih dan nyaman, (4) Nyaman dalam bertugas, (5) Pujian. Adapun jenis dan hasilnya sebagai berikut: 


\section{Pendidikan dan Pelatihan (diklat)}

Berdasarkan hasil wawancara yang dilakukan peneliti maka dapat dinyatakan bahwa guru telah merasa puas dengan diadakannya diklat yang pernah diikuti oleh guru-guru karena memberikan manfaat baik berupa peningkatan kemampuan, peningkatan pengetahuan, dan sikap sehingga dapat digunakan untuk meningkatkan suatu kinerja.

2. Promosi

Promosi merupkan suatu perpindahan dari suatu jabatan ke jabatan yang lain yang mempunyai status dan tanggung jawab yang lebih tinggi. Dalam penelitian ini menunjukkan bahwa kesempatan guru dalam memperoleh promosi sudah cukup baik, artinya guru memiliki kesempatan yang sama dan merata untuk mendapatkan promosi, namun promosi diberikan kepada guru yang memiliki kualifikasi yang cukup baik dan adanya keinginan untuk mendapatkan sebuah promosi.

3. Lingkungan Kerja

Lingkungan kerja dalam sebuah organisasi akan mempunyai suatu peranan yang sangat penting karena lingkungan kerja akan dapat mempengaruhi suatu karyawan dalam melaksanakan tugasnya. Begitu juga apabila lingkungan kerja di lingkungan karyawan cukup nyaman, bersih serta mendukung pasti akan membuat kinerja karyawan akan lebih bersemangat dalam bekerja. Berdasarkan hasil penelitian menyatakan bahwa informan menginginkan adanya lingkungan kerja yang nyaman dan bersih agar terciptanya suatu lingkungan yang kondusif yang mengakibatkan kenyamanan dalam bekerja sehingga akan meningkatkan kinerja bagi guru. Oleh karena itu keberihan lingkungan sekolah serta rasa nyaman yang ada dilingkungan sekolah sangat diperlukan atau di butuhkan guru agar apa yang dikerjakan menjadi lebih fokus dan mengahsilkan hasil yang berkualitas juga tentunya.

1. Nyaman dalam bertugas.

Selain lingkungan yang bersih pastinya seseorang juga akan mengharapkan mendapatkan adanya rasa nyaman dalam bertugas karena juka lingkungan yang bersih otomatis juga akan merasakan suatu kenyamanan dalam bertugas, namun bukan hanya lingkungan bersih saja yang membuat para guru merasa nyaman dalam bertugas atau bekerja namun juga ada keterlibatan sesama guru, melalui wawancara yang dilakukan peneliti bahwa guru juga mengharapkan rasa tenggang rasa serta saling mendukung antara guru satu dengan guru lainnya karena jika tidak ada kerjasama diantaranya pasti akan timbul rasa dan sikap perselisihan yang ungkin itu akan menghambat kenyamanan guru dalam bekerja, oleh karena itu dibutuhkan kerjasama dan saling mendukung antara sesama guru akan tercipta suatu kinerja kondusif dan tujuan sekolahpun juga dapat dicapai dengan baik jika seluruh anggta sekolah saling bekerjasama dan saling menghargai sesamanya.

5. Pujian

Pada dasarnya setiap individu akan mendapatkan suatu hal timbal balik jika kita melakukan apa yang sesuai dengan aturannya. Berdasarkan hasil penelitian bahwa guru juga mendapatkan pujian jika guru telah melaksakan tugas serta tindakan yang baik, hal inilah yang membuat guru merasa dihargai karena pekerjaan yang dikerjakan dengan baik mendapatkan suatu penghargaan atau respon yang baik sehingga mengakibatkan guru bersemangat dalam bekerja.

\section{Pembahasan}

Melalui pendidikan dan pelatiahan guru mendapatkan banyak manfaat untuk mengembangkan potensi serta kreatifitasnya yang dimana melalui wawancara dengan adanya diklat guru mendapatkan banyak manfaat pelatihan dan pendidikan yang diterima yang sebelumnya guru kurang memahami namun setelah diadaknnya diklat guru mendapatkan suatu bekal pembelajaran yang nanti akan diberikan kepada peserta didik sesuai dengan apa yang guru dapat saat diadakannya diklat, melalui diklat juga guru bisa lebih kreatif dan inovatif dalam proses pembelajaran ini juga akan membuat dampak yang positif terhadap siswa karena akan mendapat banyak inovasiinovasi dari pendidik. Kemudian melalui diklat guru mampu membuat rancangan rencana pembelajaran dengan baik karena sebelumnya diadakan diklat pastinya guru pasti tidak akan bisa menyesuaikan kurikulum 13 yang baru, namun setelah diadakannya diklat guru lebih terarah untuk membuat RPP maupun mengimplikasiannya kepada siswa, namun kendala yang dirasakan oleh guru dalam diadakannya diklat ini hanya masalah biaya dimana guru menanggung segala pembiayaan, namun sebenarnya biaya yang dikeluarkan guru ini akan sebanding dengan apa yang diperoleh nanti kedepannya karena pasti akan mendapatkan ilmu yang banyak serta berguna untuk guru dan tentu akan berdampak baik juga kepada siswa. Selain mampu mengguanakan kurikulum baru serta membuat RPP guru juga mampu membuat media pembeljaran yang menarik bagi siswa, guru mempunyai sebuah kreatifitas yang baik dalam mengembangkan media yang digunakan dalam sistem belajar mengajar, dengan adanya media siswa juga akan lebih terfokus dan lebih memahami apa yang diajarkan guru dan mampu membuat siswa aktif dalam proses pembelajaran. Dalam observasi yang dilakukan peneliti juga menunjukkan bagaimna guru menggunakan alat media pembelajran untuk mengajar siswa kemudian siswa aktif dalam menanggapi proses pembelajaran, namun ada juga guru yang kurang mampu menggunakan media pembelajaran karena faktor usia yang mungkin kurang mampu membuat media pembelajaran, namun ada juga 
kendala yang dialami oleh guru meskipun sudan mengikuti diklat yaitu kurang mmapu menguasai komputer, sebenarnya guru sudah berusaha belajar menggunakan komputer hanya saja terkadang mereka sering lupa untuk mengoprasikan komputer tersebut.

Hasil pengamatan dokumen dari observasi juga menemukan sebuah silabus yang disusun oleh guru yang berisi informasi mengenai hal-hal yang akan direncanakan oleh guru untuk diterapkan dalam proses pembelajaran, salah satunya adalah menggunakan sumber belajar, sumber belajar disini sangat penting dalam proses pembelajaran yang dapat berupa buku teks, media cetak maupun elektronika, serta lingkungan sekitar. Pemilihan sumber belajar yang tepat pasti akan membuat rangsangan kepada siswa untuk belajar dan mempercepat pemahaman dan penguasaan mengenai pembelajaran yang dipelajari. Dalam hasil penelitian mengenai promosi guru menjadi lebih bersemangat kerja karena mempunyai motivasi untuk mengalami peningkatan kariernya sehingga pemberian promosi tentunya akan memberikan sebuah peningkatan kinerja oleh guru.

Dalam observasi yang dilakukan peneliti juga mengamati setiap guru datang tepat waktu dalam setiap kali datang ke sekolah, hal tersebut dibuktikan peneliti saat datang untuk mengamati bagaimana ketepatan waktu yang dilakukan oleh para guru, hal tersebut membuktikan bahwa guru melakukan kinerjanya dengan baik dengan datang tepat waktu pada ketentuan yang ditetapkan sekolah. Namun peneliti juga menemukan bahwa ketika guru tidak mampu datang ke sekolah guru hanya menitipkan salam kepada sesama teman atau langusng kepada sekolah hanya tidak menggunakan surat ijin, hal inilah yang mungkin nanti akan menimbulkan suatu kecurigaan maupun indikasi kecurangan yang dilakukan oleh guru.

\section{SIMPULAN} berikut:

Dari hasil penelitian yang telah dipaparkan pada bab sebelumnya, maka dapat ditarik kesimpulan sebagai

1. Latar belakang diadakannya kompensasi non finansial karena adanya suatu keinginan guru untuk mendapatkan suatu kepuasan diri dan kenyamanan dalam bekerja serta kenyamanan dalam bertugas sehingga kinerja guru akan semakin meningkat kemudian juga adanya keinginan untuk cepat naik pangkat atau golongan dalam waktu yang tepat atau tidak tertunda.

2. Kompensasi non finansial yang diberikan di SDN Tinap 2 berupa (1) pendidikan dan pelatihan (diklat), (2) Promosi, (3) lingkungan yang bersih dan nyaman, (4) Nyaman dalam bertugas, (5) Pujian.

3. Pemberian kompensasi non finansial memberikan pengaruh terhadap kinerja guru SDN Tinap 2 Kecamatan sukomoro Kabupaten Magetan hal ini dibuktikan dengan adanya hasil observasi yang dilakukan peneliti dengan adanya diklat guru mampu lebih mudah dalam membuat RPP serta mampu lebih kreatif dan inovatif dalam membuat media pembelajaran. Kemudian dengan adanya promosi guru menjadi lebih bersemangat dalam pencapaian karier yang lebih tinggi dalam hasil penelitian mengenai promosi guru menjadi lebih bersemangat kerja karena mempunyai motivasi untuk mengalami peningkatan kariernya sehingga pemberian promosi tentunya akan memberikan sebuah peningkatan kinerja oleh guru. Melalui lingkungan kerja juga guru akan mendapatkan suatu kenyamanan dalam bertugas sehingga kinerja guru juga akan lebih menyenangkan karena lingkungannya yang nyaman. Begitu juga dengan adanya nyaman bertugas karena itu dibutuhkan kerjasama dan saling mendukung antara sesama guru akan tercipta suatu kinerja kondusif dan tujuan sekolahpun juga dapat dicapai dengan baik jika seluruh anggota sekolah saling bekerjasama dan saling menghargai sesamanya. Kemudian dengan adanya pujian jika guru telah melaksakan tugas serta tindakan yang baik, hal inilah yang membuat guru merasa dihargai karena pekerjaan yang dikerjakan dengan baik mendapatkan suatu penghargaan atau respon yang baik sehingga mengakibatkan guru bersemangat dalam bekerja.

\section{Saran}

Berdasarkan hasil penelitian yang dijelaskan di atas, maka penulis menyarankan hal-hal sebagai berikut:

1. Bagi Dinas Pendidikan Kabupaten Magetan sebagai lembaga yang menaungi seluruh sekolah hendaknya memberikan fasilitas-fasilitas yang mampu membantu guru dalam mempermudah mendapatkan kompemnsasi, misalnya melalui diklat Dinas Pendidikan mampu memberikan setidaknya bantuan dana untuk diadakannya diklat.

2. Bagi Kepala Sekolah sebagai pimpinan hendaknya lebih memperhatikan pemberian kompensasi non finansial yang diberikan kepada guru agar guru mendapatkan peningkatan dalam kinerjanya.

3. Bagi guru, harus mampu mempertanggung jawabkan kompensasi non finansial yang telah diterimanya yaitu dengan meningkatkan kinerjanya.

\section{DAFTAR PUSTAKA}

Arikunto, Suharsimi. (2013). Prosedur Penelitian: Suatu Pendekatan Praktik. Jakarta: Rineka Cipta 
Barnawi \& Mohammad Arifin. (2012). Instrumen Pembinaan Peningkatan \& Kinerja Guru Profesional. Yogyakarta: AR-RUZZ Media

Danim. (2011). Pengembangan Profesi Guru : Dari Pra-Jabatan, Induksi, ke Profesional Madani.Jakarta: Kharisma Putra Utama

Daryanto. (2013). Standar Kompetensi dan Penilaian Kinerja Guru Profesional. Yogyakarta: Gava Media

Djamarah, S.B. (2010). Guru dan Anak Didik dalam Interaksi Edukatif: Pedoman bagi Mahasiswa PPL guru alumni PLPG, PKG, dan PPG dalam Upaya Mengoptimalkan Aktivitas Belajar Anak Didik. Jakarta: Rineka Cipta

Fahmi, I. (2016). Pengantar Manajemen Sumber Daya Manusia: Konsep dan Kinerja. Jakarta: Mitra Wacana Media

H.B.Sutopo. 2002. Metodologi Penelitian Kualitatif. Surakarta: Universitas Sebelas Maret Press

Husien. L. (2017). Profesi Keguruan Menjadi Guru Profesional. Yogyakarta: Pustaka Baru Press

Irawan, D.H. et al. (2014). "Pengaruh Kompensasi Finansial dan Non Finansial terhadap Kinerja (Studi pada Agen AJB Bumiputera 1912 Kantor Cabang Blitar". Jurnal Administrasi Bisnis (JAB). 13(1)

Kompri. (2016). Manajemen Pendidikan: Komponen-komponen Elementer Kemajuan Sekolah. Yogyakarta: ARRUZZ Media

Kunandar. (2007). Guru Profesional Implementasi Kurikulum Tingkat Satuan Pendidikan KTSP dan Sukses dalam Sertifikasi Guru. Jakarta: PT RajaGrafindo Persada

Majid. A. (2007). Perencanaan Pembelajaran Mengembangkan Standar Kompetensi Guru. Bandung: PT. Remaja Rosdakarya

Malawi, I. (2015). Penelitian Pendidikan. Magetan: CV. AE Media Grafika

Miles \& Huberman. (1992). Analisis Data Kualitatif: Buku Sumber tentang Metode-metode Baru. Jakarta: Universitas Indonesia

Moleong. (2014). Metodologi Penelitian Kualitatif. Bandung: PT. Remaja Rosdakarya

Mulyasa. (2013). Uji Kompetensi dan Penilaian Kinerja Guru. Bandung: PT. Remaja Rosdakarya

Nurjahjani. F, (2007). "Pengaruh Imbalan Ekstrinsik terhadap Prestasi Kerja (Studi Kasus pada Karyawan Bagian Pemasaran Asuransi Jiwa Bumi Asih Jaya Cabang Malang). Jurnal Modernisasi, 3(1)

Nurul, A.Y. (2010). "Pengaruh Kompensasi dan Motivasi terhadap Kinerja Guru di SMA Negeri 2 Argamakmur Bengkulu Utara". Jurnal Pendidikan Triadik, 13 (1)

Nasution. (2012). Metode Research: Pendidikan Ilmiah. Jakarta: Bumi Aksara

Republik Indonesia. (2010). Undang-Undang Republik Indonesia Nomor 14 Tahun 2005 tentang Guru Dan Dosen.

Rivai. V. (2005). Manajemen Sumber Daya Manusia untuk Perusahaan: Dari Teori ke Praktik. Jakarta: PT.RajaGravindo Persada

Riyadi. (2011)."Pengaruh Kompensasi Finansial, Gaya Kepemimpinan, dan motivasi Kerja terhadap Kinerja Karyawan pada Perusahaan Manufaktur di Jawa Timur". Jurnal Manajemen dan Kewirausahaan, 13(1)

Rofiq, A. (2013). Pengaruh Kemampuan Manajerial Kepala Sekolah dan Kompensasi Non Finansial terhadap Kinerja Guru Sekolah Menengah Pertama Negeri Se-Kabupaten Sleman. Skripsi. Universitas Negeri Yogyakarta

Samputri. (2012). Analisis Sistem Pemberian Kompensasi dan Faktor-faktor yang Mempengaruhi pada Bank BRI (Studi Kasus pada Bank Rakyat Indonesia (Persero) Tbk. Cabang Makassar A.Yani. Skripsi. Universitas Hasanuddin Makassar

Suhardiman. B. (2012). Studi Pengembangan Kepala Sekolah: Konsep dan Aplikasi. Jakarta: Rineka Cipta

Sugiyono. (2016). Metode Penelitian Kuantitatif, Kualitatif, dan R\&D. Bandung: Alfabeta, CV

Trianto. (2010). Pengantar Penelitian Pendidikan bagi Pengembangan Profesi Pendidikan dan Tenaga Kependidikan. Jakarta: Prenada Media

Ulfatin, Teguh Triwiyanto. (2016). Manajemen Sumber Daya Manusia Bidang Pendidikan. Jakarta: Rajawali Press

Yusuf, B. (2015). Manajemen Sumber Daya Manusia di Lembaga Keuangan Syari'ah. Jakarta: Rajawali Press. 